\title{
Do Producers of Accounting Software Use Social Media?
}

\author{
Libuše SVOBODOVÁ \\ University of Hradec Králové, Hradec Králové, Czech Republic \\ libuse.svobodova@uhk.cz
}

\begin{abstract}
The goal of the article is to present seven most often used accounting software and their producers in the connection with use of social networks by producers of accounting software in the Czech Republic. At the beginning there is shortly described the theoretical background. Classification of social networks, web 2.0 and accounting software are solved. The main part of the article is focused on the accounting software and analysis of social networks that are used by producers of accounting software. In the article is also analyzed whether producers use links from their web pages on the selected social networks. The topic is not often solved and is up-to-date. Primary and also secondary sources are used in the article. It was founded that most often used social network by producers of accounting software are Facebook, YouTube and Twitter. The links from web pages are often used also in the connection with Google+.
\end{abstract}

Keywords: Accounting Software, Communication, Information, Social Network, Use.

\section{Introduction}

Social networks are widely used not only in the personal life, but also in the commercial sphere. They have a lot of effects on the society. Increased online communication and fastened communication are some of them. The question may be whether the companies that produce accounting software in the Czech Republic use selected social networks for communication with their customers, potential customers, students and next audience. Selection of new accounting software was presented in the previous research done by Svobodová, Černá [22]. One of the key elements in the selection may be communication with producer of the accounting software via various channels. Author would like to focus on communication and marketing of selected companies by modern channels. The organization of the paper is follows. Firstly theoretical background is described. The main part of the article is focused on the evaluation of use of social networks by producers of accounting systems. The paper contributes to the exploration of utilization of Web 2.0 phenomenon and social networks by companies and individuals in the field of accounting software. 


\section{$2 \quad$ Literature review}

\subsection{Web 2.0}

Web 2.0 concept was defined by Tim O'Reilly in 2004 as a designation of the new generation of the Web. Reily's definition of Web 2.0 is as follows: "Web 2.0 is the business revolution in the computer industry, which is caused by deflection in the understanding of the Web as a platform. Key among those rules is this: build applications that will be better and better due to the network effect with an increasing number of people." [18]

\subsection{Social networks}

A sociologist J. A. Barnes (1954) is considered to be the author of the definition of the social network. The term social network is associated with the Internet and directly with the social networks on the Internet. But this is not the only connection there is a need to deal with the concept of social network from the sociological point of view, therefore, the social network can be described as a "map of the area near and distant surroundings where relationships of involved people are defined." [5]

Social network on the Internet is considered to be a group of people who communicate and share documents and information on users. The Social Network concept is described and defined by Boyd and Ellison: Social networking is defined as a web service that allows individuals to create a public or semi-public profile within the bounded system, create a group of users with whom they share a connection, and browse the list of own connections and that created by other users of the system [6]. The most often used social networks Facebook, Instagram and Twitter were presented in previous article of Černá, Svobodová [9] or YouTube in Svobodová [23].

Over the last few years, online social networks such as Facebook and Twitter have experienced exponential growth in both profile registrations and social interactions. These networks allow people to share different information ranging from news, photos, videos, feelings, personal information or research activities. [2]

Social networks have global popularity. One of the most common online activities in the EU-28 in 2015 was participation in social networking. Half $(50 \%)$ of individuals aged 16 to 74 used the internet for social networking, for example using sites such as Facebook or Twitter in the EU. According to Eurostat [13] 45\% of individuals use social networks in the Czech Republic.

\subsection{Social media}

Social media are applications which become social networks via users' use.

Social media are a form of electronic communication (social networking and microblogging networks), through which users create online communities to share information, ideas, personal messages and other content (videos). [20] Social media can be divided on the basis of their focus, and also according to marketing tactics. Social media according to the marketing tactics is considered to be more transparent than on their 
focus. Also surveys on utilization of social media are more frequently conducted on the basis of marketing media division:

- Social networks (Facebook, MySpace, LinkedIn).

- Blogs, video blogs, microblogs (Twitter).

- Discussion forums, Q \& A portals (Yahoo Answers).

- Wikis (Wikipedia, Google Knol).

- Bookmarking systems (Digg, Delicious, Jagg).

- Shared multimedia (YouTube, Flickr).

- Virtual worlds (Second Life, The Sims). [16]

How Brand Actions and User Actions Influence Brand Value by use of social networks is solved in [8] and performance measurement system to quantify the contribution of social media is presented in [3]. Du and Jiang [11] find that firm use of social media is associated with firm performance, measured by stock price and return on assets. When testing the individual association of the various platforms and firm performance, the authors find that only Facebook and Twitter has a statistically significant relationship. They observe that half of the firms use one or both of these platforms.

\subsection{Accounting software}

The term refers to software accounting software that handles accounting and financial processes. The offer of accounting software focuses on the specific size of the company. According to company size amount of income, the number of transactions processed and the number of employees differs. [10]

\section{Methodology and goal}

The article was prepared on the basis of print and electronic resources. Specialized articles that deal with issue of financial accounting or social media can be found. By contrast, printed literature on accounting (economic) software doesn't nearly occurs on the Czech market. Available books on accounting are primarily concerned with the processing and are intended for teaching or as a handbook for accountants. Specialized materials in the field of information technology are in particular focused on the area of enterprise information technologies and their application. Publications on ERP systems are available in this field and in most cases they contain accounting (economic) software, but they do not aim deeper on it. In contrast to the situation on the Czech market there are a lot of foreign sources abroad.

In case that we link those two areas together (accounting software and their producers and social networks) there are not a lot of articles focused on this issue. The existing literature focused separately on the accounting software and Facebook or social media or social network in the connection of promotion of the brand or product, communication with customers or training etc. There were not founded relevant articles in databases Web of Knowledge or Scopus focused on the interconnected topic. This topic is 
still in its infancy. The intention of the article is to stimulate a conversation and proposes ways in which to frame early and future research.

The main part of the article is based on the available resources of the most often used accounting software and their producers in the Czech Republic. Selected accounting software will be applicable for SME. The selection was done due the highest proportion on the market. In the next step was done analysis whether the producers of accounting software use selected social networks or not and whether are web pages of the producers connected with their social networks.

The goal of the article is to present the most often used accounting software, their producers in the connection with use of social networks by producers of accounting software and links with producer's web pages in the Czech Republic.

\section{Results}

The first part contains the results of selection from accounting software products and their producers. Data were taken over from the SystemOnLine website [24] which deals with statistical data about accounting, economic and ERP systems and with their use, information about functions, prices etc. Into consideration will be taken accounting software for basic SME in the Czech Republic. The second part contains information about social network Facebook, YouTube, Twitter, Instagram and their use by accounting software producers. Next topic is focused on the interconnection of social networks with web pages of companies. Topics of producers of accounting software and communication via social networks were connected because companies are searching how to save money in all areas of doing business, earn more money, have a larger share on the market and other goals. Social media are very often perceived as the possibility how to save money in the communication with customers and how to engage attention. Contrary people like to use social networks that are nowadays modern, popular and often used not only by one generation.

\subsection{Accounting software and producers}

On the basis of gained results from the investigation a selection of the below discussed results have been made utilizing SystemOnLine website. Individual companies regularly update detailed information about accounting software products, including the number of installations, number of hot-line workers, number of consultants of the product, functions of the product, price, etc. In the filter it was firstly entered - find a product that has more than 10,000 installations'. The following products were displayed: Ekonom, Pohoda, Money S3 and "Účto" (Accounting). Due the larger sample of the companies was the selection repeated with the smaller number of installations that were reduced on 5,000 installations. Into research will be added Abra Gen, Helios Orange and Stereo Ježek Software. In the next search specific data of all other products were found. Table 1 shows all the above mentioned accounting software and ERP systems. Pohoda and Money are the most widely used box systems in the Czech Republic. Pohoda is with more than 200,000 licenses and Money S3 with 60,000 licenses. 
Important are also information about workers on hot-line. Some data were not by the companies filled in. From accessible sources it is possible to mention, that the biggest number of workers on hot-line is in company Asseco Solutions. It can be connected also with their other products that they offer to bigger companies. Asseco has also the biggest number of the consultants. Účto Tichý and Stereo Ježek Software are cooperating companies. Účto Tichý has software for individuals that lead single-entry bookkeeping and Ježek Software for corporate bodies that lead double-entry bookkeeping.

Table 1. Accounting software, more than 5,000 installations [24, own elaboration]

\begin{tabular}{|c|c|c|c|c|c|}
\hline $\begin{array}{l}\text { Name } \\
\text { product }\end{array}$ & $\begin{array}{l}\text { Name of } \\
\text { producer }\end{array}$ & $\begin{array}{l}\text { Number of } \\
\text { installations }\end{array}$ & $\begin{array}{l}\text { Size of the } \\
\text { biggest } \\
\text { installation }\end{array}$ & $\begin{array}{l}\text { Workers } \\
\text { on hot-line }\end{array}$ & $\begin{array}{l}\text { Number of } \\
\text { consultants of } \\
\text { the product }\end{array}$ \\
\hline Pohoda & Stormware & $200000+$ & 60 & 76 & 100 \\
\hline Money S3 & $\begin{array}{l}\text { Cígler } \\
\text { Software }\end{array}$ & 60000 & 50 & 65 & 120 \\
\hline Ekonom & Elisoft & 30000 & 15 & 8 & 15 \\
\hline Účto Tichý & Tichý \& spol. & 24200 & & 4 & A few tens \\
\hline Abra Gen & $\begin{array}{l}\text { Abra } \\
\text { Software }\end{array}$ & 9400 & & 20 & 64 \\
\hline Helios Orange & $\begin{array}{l}\text { Asseco } \\
\text { Solutions }\end{array}$ & 6088 & 250 & 101 & 203 \\
\hline $\begin{array}{l}\text { Stereo Ježek } \\
\text { Software }\end{array}$ & $\begin{array}{l}\text { Ježek } \\
\text { Software }\end{array}$ & 5000 & & 8 & 44 \\
\hline
\end{tabular}

\subsection{Accounting software, web pages and social networks}

In the next part of the research there were analysed social networks Facebook, Twitter, Instagram, YouTube and others in the connection with producers of accounting software in the Czech Republic. It was searched whether or not have the producers of accounting software account on the widely used social network Facebook or on others. Accounts of the individual brands were searched on the all mentioned social networks. Results are presented in table 2.

Table 2. Accounting software and social networks [14, 15, 25, 27 own elaboration]

\begin{tabular}{lcccc}
\hline & Facebook & YouTube & Twitter & Instagram \\
\hline Pohoda & $\mathrm{X}$ & $\mathrm{X}$ & $\mathrm{X}$ & - \\
Money S3 & $\mathrm{X}$ & $\mathrm{X}$ & - & - \\
Ekonom & $\mathrm{X}$ & $\mathrm{X}$ & - & - \\
Účto Tichý & $\mathrm{X}$ & $\mathrm{X}$ & - & - \\
Abra Gen & $\mathrm{X}$ & $\mathrm{X}$ & $\mathrm{X}$ & - \\
Helios Orange & $\mathrm{X}$ & $\mathrm{X}$ & $\mathrm{X}$ & - \\
Stereo Ježek Software & $\mathrm{X}$ & $\mathrm{X}$ & $\mathrm{X}$ & - \\
\hline
\end{tabular}

The table above presented use of the selected social networks by producers of the accounting software. It was founded that all producers use social networks Facebook and YouTube for communication with audience. Twitter use only three from seven 
investigated companies. It was Abra Software, Asseco Solutions and Ježek Software. Producers do not use Instagram for communication with audience.

Table 3 presents interconnection between web pages and direct links on social networks where their accounts were founded.

Table 3. Direct links between companies social networks and www $[4,7,12,14,15,17,21$, 25, 26, 27 own elaboration]

\begin{tabular}{lccccc}
\hline & $\begin{array}{c}\text { www }+ \\
\text { Facebook }\end{array}$ & $\begin{array}{c}\text { www } \\
\text { Twitter }\end{array}$ & $\begin{array}{c}\text { www } \\
\text { Instagram }\end{array}$ & $\begin{array}{c}\text { www }+ \\
\text { YouTube }\end{array}$ & $\begin{array}{c}\text { www }+ \\
\text { Google+ }\end{array}$ \\
\hline Pohoda & $\mathrm{X}$ & $\mathrm{X}$ & - & - & $\mathrm{X}$ \\
Money S3 & $\mathrm{X}$ & - & - & - & $\mathrm{X}$ \\
Ekonom & $\mathrm{X}$ & - & - & - & - \\
Účto Tichý & - & - & - & - & - \\
Abra Gen & $\mathrm{X}$ & $\mathrm{X}$ & - & $\mathrm{X}$ & $\mathrm{X}$ \\
Helios Orange & $\mathrm{X}$ & $\mathrm{X}$ & - & $\mathrm{X}$ & - \\
Stereo Ježek Software & $\mathrm{X}$ & $\mathrm{X}$ & - & - & $\mathrm{X}$ \\
\hline
\end{tabular}

It was founded that all companies instead Účto Tichý have direct links of their Facebook profile. All users that use Twitter have also interconnection between webpages and social network. Companies do not use Instagram. Also on their web pages were not founded links. Even though all companies use YouTube, the direct link from the first page uses only two companies Abra Software and Asseco Solutions. On the webpages were also founded next links on others social networks. Four companies use Google+ and have direct link.

Other social networks are also used. Money S3 has the link on their Skype. Cígler Software, Abra Software and Asseco Solutions also uses LinkedIn and have direct link on their webpages. Asseco Solutions use also blog.

\section{Conclusion and discussion}

Virtual space has been giving our real world new dimension. Creativity, originality and innovations are valued characteristics. Social networks fit knowledge management as they open the door to new ways of communication, enable development, editing, sharing and storing materials on the virtual platform. Social networks are nowadays one of the most popular and most often used channels to inform and communicate not only in the private sphere but also in the corporate settings.

The goal of the article was to present the most often used accounting software, their producers in the connection with use of social networks by producers of accounting software and links with producer's web pages in the Czech Republic.

It has been founded that all producers use Facebook and YouTube. Only four from analyzed companies use Twitter and no one is using Instagram. As far as the connectivity of web pages and social networking sites was concerned that there are missing some links on the web pages. Účto Tichý is missing link of Facebook. On YouTube are 
missing links by Stormware and Stereo Ježek SW. Google+ and interconnection with www pages use four companies.

In future there is potential for an interesting area of exploration. It can be investigated the number of posts, topics of posts, focusing, like, tracking, tweets, mobile apps, their use, training and posts on YouTube, benefits for producers, benefits for users of software and other areas related to informing existing users as well as new users for the software can be found in more depth.

\section{Acknowledgement}

This paper is supported by specific project No. 2103/2017 "Investment evaluation within concept Industry 4.0" at Faculty of Informatics and Management, University of Hradec Kralove, Czech Republic. We would like to thank student Marta Martinova for cooperation in the processing of the article.

\section{References}

1. Abra Software, https://www.abra.eu/, last accessed 2017/10/10

2. Adewole, K.S., Anuar, N.B., Kamsin, A., Varathan, K.D., Razak, S.A.: Malicious accounts: Dark of the social networks, Journal of Network and Computer Applications, Vol. 79, pp. 41-67 (2017).

3. Agostino, D., Sidorova, Y.: A performance measurement system to quantify the contribution of social media: new requirements for metrics and methods, Measuring Business Excellence, Vol. 20(2), pp. 38-51 (2016).

4. Asseco Solutions, http://www.helios.eu/, last accessed 2017/10/10

5. Barnes, J.... Class and Committees in a Norwegian Island Parish. Human Relations, (7) pp. 39-58. (1954)

6. Boyd, D.M., Ellison, N.B.: Social network sites: definition, history, and scholarship. J. Computer-Mediated Commun. 13(1), pp. 210-230 (2007).

7. Cígler Software, http://www.money.cz/, last accessed 2017/10/10

8. Colicev, A, O'Connor, P. Vinzi, VE.: Is Investing in Social Media Really Worth It? How Brand Actions and User Actions Influence Brand Value. Service Science. Vol. 8(2), pp. 152168 (2016).

9. Černá, M., Svobodová, L, Haviger, J.: Perception and Utilization of Facebook by University Students: Case Study. Proceedings of the 15th European Conference on e-learning (ECEL), pp. 105-113 (2016).

10. Dočkalová, P.: Criteria for selection of an economic system. IT Systems: With an overview of the world of information technology, 11/2008, http://www.systemonline.cz/ekonomickesystemy/kriteria-pick-economic-system-1.htm, last accessed 2017/10/10

11. Du, H., . Jiang., W.: Do social media matter? Initial empirical evidence. Journal of Information Systems. Vol. 29(2) (2015).

12. Elisoft, Ekonom, http://www.ekonom-system.cz/cz/home, last accessed 2017/10/10

13. Eurostat. Digital economy and society statistics - households and individuals, http://ec.europa.eu/eurostat/statistics-explained/index.php/Digital_economy_and_society_statistics__households_and_individuals (2015), last accessed 2017/10/10

14. Facebook, https://www.facebook.com/, last accessed 2017/10/10 
15. Instagram, https://www.instagram.com/, last accessed 2017/10/10

16. Janouch, V.: Internetový marketing Prosad’te se na webu a sociálních sítích. Brno: Computer Press, 216 p. (2010)

17. Ježek Software, https://www.jezeksw.cz/, last accessed 2017/10/10

18. O'Reilly, T.: What is Web 2.0: Design Patterns and Business Models for the next generation of software, http://www.oreillynet.com/pub/a/oreilly/tim/news/2005/09/30/what-is-web20.html, last accessed 2017/10/10

19. Socialbakers, https://suite.socialbakers.com/234916/analytics/?c-d1=last-30\&c-l=0, last accessed 2017/10/10

20. Social media - Definition and More from the Free Merriam. Webster Dictionary. http://www.merriam-webster.com/dictionary/social\%20media, last accessed 2017/10/10

21. Stormware, https://www.stormware.cz/, last accessed 2017/10/10

22. Svobodová, L., Černá, M.: Accounting, Economic and ERP Systems on the Czech Scene. Advanced Science Letters, 22(5-6), pp. 1170-1174 (2016).

23. Svobodová, L.: Utilization and Benefits of YouTube for the Educational Purposes: a Review Study. Proceedings of the 15th European Conference on e-learning (ECEL), pp. 789-793 (2016).

24. System online, http://www.systemonline.cz/prehled-informacnich-systemu/ekonomickesystemy, last accessed 2017/10/10

25. Twitter, https://twitter.com/, last accessed 2017/10/10

26. Účto Tichý, https://www.ucto-tichy.cz/, last accessed 2017/10/10

27. YouTube, https://www.youtube.com/, last accessed 2017/10/10 